\title{
Deposits of $\alpha_{2} \mathrm{M}$ in the rheumatoid synovial membrane
}

\author{
E. D. FLORY, B. J. CLARRIS, AND K. D. MUIRDEN \\ From the University of Melbourne, Department of Medicine, Royal Melbourne Hospital, Victoria 3050, \\ Australia
}

SUMMARY Synovial tissue from patients with rheumatoid arthritis, systemic lupus erythematosus, osteoarthritis, and having menisectomies was examined by immunofluorescence for deposits of alpha-2-macroglobulin $\left(\alpha_{2} \mathrm{M}\right)$. In inflammed tissues, $\alpha_{2} \mathrm{M}$ was found in the synovial lining cells and in perivascular cells. The amount of $\alpha_{2} \mathrm{M}$ correlated with the degree of inflammation. Similarly, free lining cells obtained by trypsination of the intact synovial membrane contained identical inclusions. $\alpha_{2} \mathrm{M}$ was not detected in the menisectomy cases and in the less inflammatory osteoarthritic specimens. In-vitro studies demonstrated uptake of $\alpha_{2} \mathrm{M}$-trypsin complexes but not of native $\alpha_{2} \mathrm{M}$ by most of the cultured synovial cells whether they came from rheumatoid patients or controls. The internalised complexes disappeared within 12 hours of culture. The results suggest that $\alpha_{2} \mathrm{M}$ proteinase complexes formed in the joint are taken up by phagocytic synovial and perivascular cells in a similar way to immune complexes.

During inflammation proteinases are released from inflammatory cells such as macrophages and neutrophil leucocytes ${ }^{12}$ and also from tissue cells such as chondrocytes ${ }^{3}$ and synovial lining cells (LC). ${ }^{4}$

In the inflamed joint proteinases are considered a major cause of tissue destruction. Normally these enzymes become inactivated by various inhibitors: in plasma and synovial fluids, alpha-l-antitrypsin $\left(\alpha_{1} \mathrm{AT}\right)$ and alpha-2-macroglobulin $\left(\alpha_{2} \mathrm{M}\right)$ are the main inhibitors. ${ }^{5}$ In the circulation $\alpha_{2} \mathrm{M}$-proteinase complexes are removed by fixed tissue macrophages of the liver or spleen and then broken down. ${ }^{6}$ In inflammatory exudates $\alpha_{2} \mathrm{M}$ is partly complexed to proteinases. ${ }^{78}$ In previous work inclusions of $\alpha_{2} \mathrm{M}$ probably corresponding to $\alpha_{2} \mathrm{M}$-proteinase complexes were found in synovial fluid monocytes from inflamed joints. ${ }^{9}$ Because changes in the synovial membrane and its extension as pannus are such a significant part of rheumatoid pathology, and as synovial tissue itself is known to produce catabolic enzymes, ${ }^{10}{ }^{11}$ it was decided to look for the enzyme inhibitor $\alpha_{2} \mathrm{M}$ in synovial tissues. This would involve an immunofluorescent method allowing comparison with the distribution of immunoglobulin deposits of which are known to be present in the synovial membrane.$^{12}$ In this study specimens of rheumatoid tissue removed at surgery have been studied and the results

Accepted for publication 3 September 1981.

Correspondence to Dr E. D. Flory. compared with less inflammatory tissue from patients with osteoarthritis. Having found granular deposits of $\alpha_{2} M$ in lining cells in inflamed synovial membranes we decided to study the uptake of free or complexed $\alpha_{2} \mathrm{M}$ by synovial cells in tissue culture.

\section{Material and methods}

TISSUES

Specimens of synovial membrane from 21 patients were obtained at arthroplasty, synovectomy, or menisectomy, or by needle biopsy, from the following patients: 10 patients with rheumatoid arthritis (RA), 1 with systemic lupus erythematosus (SLE), 8 with osteoarthritis (OA), and 2 undergoing menisectomy for slight tears.

The specimens were collected in ice-cold isotonic saline, processed, and embedded in paraffin according to Sainte-Marie. ${ }^{13}$ The blocks were stored at $4^{\circ} \mathrm{C}$ for less than a month before sectioning. The $3 \mu \mathrm{m}$ thick sections were stained immediately after removal of paraffin.

\section{IMMUNOFLUORESCENT STAINING}

Immunofluorescent staining was carried out at room temperature in moist chambers following the procedure of Johnson and Holborow. ${ }^{14}$ For detection of immunoglobulins (Ig) and fibrin the direct method of staining was used, and for $\alpha_{2} \mathrm{M}$ and $\mathrm{C} 3$ the indirect 
method. To detect concomitant localisation of $\alpha_{2} \mathrm{M}$ and $\mathrm{Ig}, \alpha_{2} \mathrm{M}$, and fibrin, or Ig and C3, direct double staining was performed.

The following immunofluorescence reagents were used: rabbit antihuman $\alpha_{2} \mathrm{M}$ fluorescein isothiocyanate conjugated (FITC) rabbit antihuman $\alpha_{2} \mathrm{M}$, rabbit antihuman fibrinogen and goat antihuman $\mathrm{Ig}$ from Behring Hoechst AG Darmstadt, W Germany; rabbit antihuman C3, from Dako-Immunoglobulins, Copenhagen, Denmark; sheep antirabbit immunoglobulins FITC from Wellcome Laboratories; rhodamine isothiocyanate (TMRITC) conjugated goat antihuman $\alpha_{2} \mathrm{M}$ from Cappel; and TMRITC conjugated goat antihuman immunoglobulin kindly given by the Pathology and Immunology Department of Monash University in Melbourne. To reduce nonspecific staining, some conjugates were absorbed with acetone dried tissue powder. ${ }^{14}$

The following tests for specificity were found to be satisfactory: (i) For direct staining tests, tissue sections were pretreated with unconjugated specific antiserum before staining with conjugated antiserum of the same origin and/or conjugates were absorbed with the appropriate antigen. (ii) Negative controls in the indirect staining technique were obtained by employing either nonimmune serum (of the same origin as the specific antiserum) or phosphate buffered saline (PBS) before staining with the conjugate.

At least 2 tissue blocks were examined from each patient with serial sections. The amount and intensity of fluorescence were evaluated arbitrarily from 0 to 3.

To correlate the fluorescent microscopy results with histology, every second section was stained with haematoxylin and eosin. The degree of inflammation was evaluated by grading proliferation of lining cells and infiltration of inflammatory cells from 0 to 3 .

\section{CELL CULTURES}

Normal synovial cells were isolated from intact joints of cadavers by instillation of trypsin into the joint cavity. ${ }^{15}$ Procedures for establishment of cell lines and maintenance of these cultures have been described previously. ${ }^{16}$ Rheumatoid synovial cultures were also isolated from intact joints by a modification of the above method ${ }^{17}$ or from explants of synovial membrane obtained at surgery. To prepare explants the synovial layer was dissected from underlying tissue and cut into pieces of approximately 1 $\mathrm{mm}$ and spaced in plastic Petri dishes. Eagle's basal medium (EBM) (Commonwealth Serum Laboratories, Parkville, Victoria) with $20 \%(\mathrm{v} / \mathrm{v})$ heat-inactivated fetal bovine serum (FBS) (Flow Laboratories) was used for the cultures. Medium was changed every 3 or 4 days.
ENDOCYTOSIS OF $\alpha_{2}$ M-PROTEINASE

COMPLEXES

All the cell lines were kept for 4 days in serum-free medium (SFM) before the endocytosis experiments. SFM (for $100 \mathrm{ml} \mathrm{sol}$ ) consisted of $97 \mathrm{ml}$ Iscove's modification of Dulbecco's medium, $0.5 \mathrm{ml}$ neomycin 1000 units, $1 \cdot 0 \mathrm{ml}$ glutamine $20 \mathrm{mM}, 1 \cdot 0 \mathrm{ml} 10 \%$ high purity albumin. The $\mathrm{pH}$ was adjusted with $\mathrm{HCl}$. The cells were then incubated with bacterial hyaluronidase (Organon, Holland) $100 \mathrm{U} / \mathrm{ml}$, in order to disperse pericellular hyaluronic acid, ${ }^{18}$ washed 3 times in Hanks's balanced salt solution (HBSS), and resuspended in EBM with $10 \%$ fresh human plasma. As purified $\alpha_{2} \mathrm{M}$ was not readily available, trypsin $(10 \mu \mathrm{g} / \mathrm{ml})$ or plasmin $(5 \mu \mathrm{g} / \mathrm{ml})$ was added to human plasma to form spontaneous $\alpha_{2}$ Mproteinase complexes as described elsewhere. ${ }^{9}$ The cells were carefully washed with $\mathrm{HBSS}$ and incubated again for 30 minutes at $37^{\circ} \mathrm{C}$ with bacterial hyaluronidase. After fixation with $95 \%$ methanol for 3 minutes the cells were stained for $\alpha_{2} \mathrm{M}$ by indirect immunofluorescence. The rabbit antihuman $\alpha_{2} \mathrm{M}$ was absorbed with FBS before use, as cross-reactions between antisera to human $\alpha_{2} \mathrm{M}$ and components of the FBS have been described. ${ }^{19}$ Inhibition of endocytosis was performed by incubating the cells at $4^{\circ} \mathrm{C}$ or by incubating cells at $37^{\circ} \mathrm{C}$ in the presence of alpha-iodoacetamide (Calbiochem, Hoechst AG).

SYNOVIAL LINING CELLS SMEARS

Smears were made with some of the cells collected by the trypsin washout procedure from rheumatoid patients. The smears were stained by an immunofluorescence technique for $\alpha_{2} \mathrm{M}, \mathrm{Ig}$, and C3 by methods described previously. ${ }^{9}$

\section{Results}

SYNOVIAL TISSUES: FLUORESCENT

MICROS COPY

Tissues which were highly inflamed histologically - and this included most of the patients with RA and the single patient with SLE-showed strong positive staining for $\alpha_{2} \mathrm{M}, \mathrm{Ig}, \mathrm{C} 3$, and fibrin both within the synovial lining cells (LC) and in the subsynovial tissue (perivascular infiltrating cells, stromal cells, and vessel endothelial cells). In general the degree of staining correlated with the degree of infiltration and LC proliferation, being higher in the very inflamed tissues. Four of the $8 \mathrm{OA}$ patients' tissues contained small amounts of $\alpha_{2} \mathrm{M}(1+)$ with or without some Ig and $\mathrm{C} 3$; when positive staining was present it was seen only in the LC, apart from one specimen in which a few perivascular cells were also positive. The 4 other OA specimens and the tissues obtained at meniscectomy were completely negative when 
stained for $\alpha_{2} \mathrm{M}, \mathrm{Ig}, \mathrm{C} 3$ or fibrin. A summary is given in Table 1.

DISTRIBUTION AND PATTERN OF

FLUORESCENT STAINING $\alpha_{2} \mathrm{M}$. In the lining cells the distribution of $\alpha_{2} \mathrm{M}$ varied. The granules were either fine and evenly spread in

Table 1 Immunofluorescence studies of synovial membranes from 21 patients

\begin{tabular}{|c|c|c|c|c|c|c|c|c|c|c|}
\hline \multirow[t]{3}{*}{ Case } & \multirow[t]{3}{*}{ Diagnosis } & & \multirow{2}{*}{\multicolumn{2}{|c|}{ Histology }} & \multicolumn{6}{|c|}{ Fluorescence } \\
\hline & & & & & \multicolumn{3}{|c|}{ Lining cells } & \multicolumn{3}{|c|}{ Subsynovial cells } \\
\hline & & & $P$ & $I$ & $\alpha_{2} M$ & $I g$ & $C 3$ & $\alpha_{2} M$ & $\operatorname{Ig}$ & $C 3$ \\
\hline 1 & RA & knee & 3 & 2 & $3+$ & $3+$ & $2+$ & $0+$ & $0+$ & $0+$ \\
\hline 2 & RA & knee & 3 & 2 & $3+$ & $3+$ & $2+$ & $2+$ & $2+$ & $0+$ \\
\hline 3 & RA & hip & 2 & 2 & $3+$ & $2+$ & $2+$ & $1+$ & $1+$ & $2+$ \\
\hline 4 & RA & $\mathrm{MCP}$ & 2 & 2 & $3+$ & $1+$ & $1+$ & $2+$ & $2+$ & $2+$ \\
\hline 5 & RA & FT & $1-2$ & 2 & $2+$ & $1+$ & - & $1+$ & - & $0+$ \\
\hline 6 & RA & elbow & $1-2$ & $1-2$ & $2+$ & $1+$ & $1+$ & $1+$ & $1+$ & $0+$ \\
\hline 7 & RA & $\mathrm{MCP}$ & 2 & 1 & $2+$ & $1+$ & $1+$ & $0+$ & - & $0+$ \\
\hline 8 & RA & FT & 1 & 1 & $2+$ & $1+$ & $1+$ & $0+$ & - & $0+$ \\
\hline 9 & RA & FT & 1 & 1 & $1+$ & $1+$ & $1+$ & $2+$ & $2+$ & $2+$ \\
\hline 10 & RA & knee & 3 & 2 & $2+$ & $1+$ & $1+$ & $1+$ & $1+$ & $1+$ \\
\hline 11 & SLE & $\mathrm{MCP}$ & 3 & 2 & $3+$ & $2+$ & $2+$ & $1+$ & $1+$ & $1+$ \\
\hline 12 & $\mathrm{OA}$ & knee & 0 & 0 & $0+$ & $0+$ & $0+$ & $0+$ & $0+$ & $0+$ \\
\hline 13 & $\mathrm{OA}$ & hip & 0 & 0 & $0+$ & $0+$ & $0+$ & $0+$ & $0+$ & $0+$ \\
\hline 14 & $\mathrm{OA}$ & hip & 0 & 0 & $0+$ & $0+$ & $0+$ & $0+$ & $0+$ & $0+$ \\
\hline 15 & $\mathrm{OA}$ & hip & 0 & 0 & $0+$ & $0+$ & $0+$ & $0+$ & $0+$ & $0+$ \\
\hline 16 & $\mathrm{OA}$ & knee & 1 & 0 & $1+$ & $0+$ & $0+$ & $0+$ & $1+$ & $1+$ \\
\hline 17 & $\mathrm{OA}$ & hip & $0-1$ & 0 & $1+$ & $1+$ & $0-1+$ & $1+$ & $1+$ & $1+$ \\
\hline 18 & $\mathrm{OA}$ & hip & 1 & 0 & $1+$ & $0+$ & $0+$ & $0+$ & $0+$ & $0-1+$ \\
\hline 19 & $\mathrm{OA}$ & knee & 1 & 0 & $2+$ & $2+$ & $1+$ & $0+$ & $0+$ & $0+$ \\
\hline 20 & Normal & knee & 0 & 0 & $0+$ & $0+$ & $0+$ & $0+$ & $0+$ & $0+$ \\
\hline 21 & Normal & knee & 0 & 0 & $0+$ & $0+$ & $0+$ & $0+$ & $0+$ & $0+$ \\
\hline
\end{tabular}

$\mathrm{MCP}=$ metacarpophalangeal joint. $\mathrm{FT}=$ flexor tendon. Fluorescence intensity produced from $0+$ to $3+$. Lining cells proliferation $(\mathrm{P})$ and inflammatory infiltrate $(\mathrm{I})$ graded from 0 to 3 .
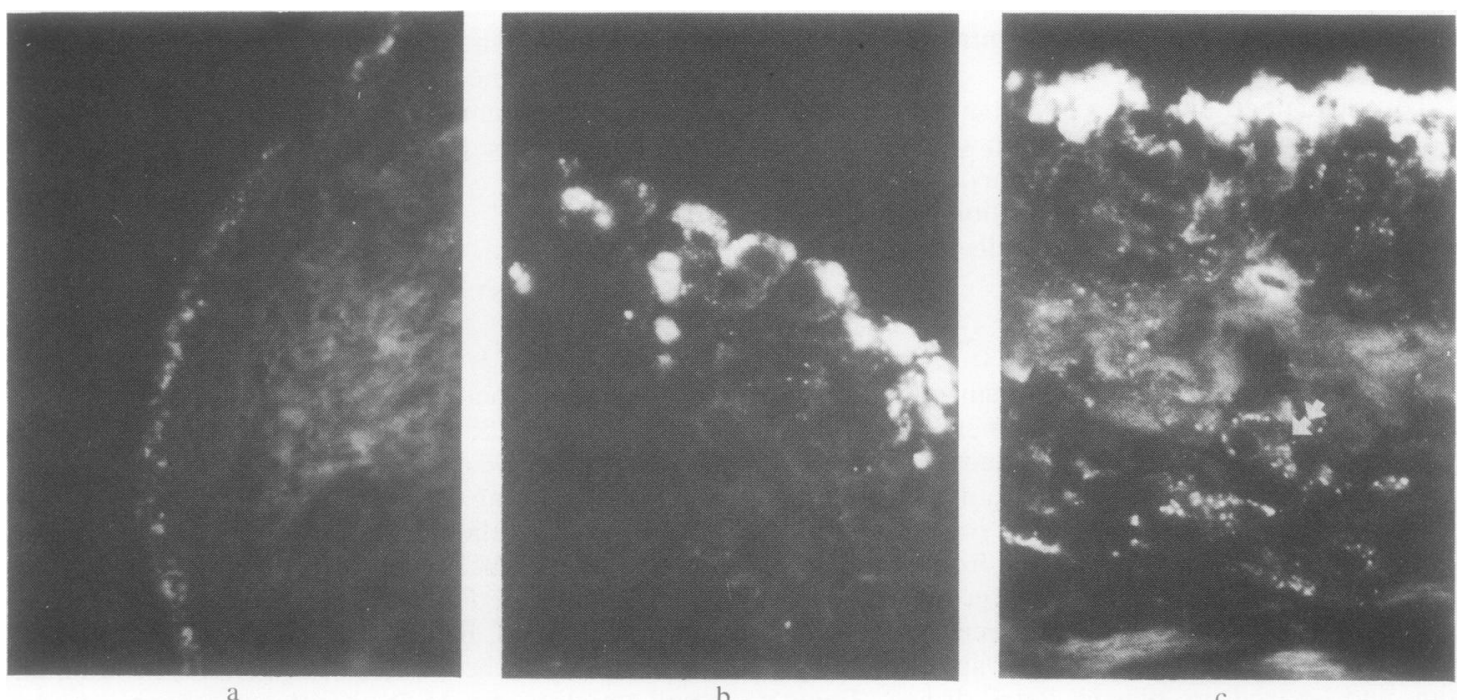

Fig. 1 Immunofluorescence staining for $\alpha_{2} M$ of synovial membrane: (a) Osteoarthritis (case 19): tissue with moderate proliferation oflining cells; deposition of $\alpha_{2} M(2+)$ evenly distributed in the lining cells throughout the membrane. $(\times 534)$. (b) Rheumatoid arthritis (case 4): deposition of $\alpha_{2} M(3+)$ in the lining cells; the deposits are collected in focal groups of cells. $(\times 630)$. (c) Rheumatoid arthritis (case 3$)$ : deposition of $\alpha_{2} M(3+)$ in the lining cells and perivascular cells $($ arrows $)$; the deposits are either coarse and dense or finely granular. $(\times 630)$ 
the cytoplasm or coarse and dense (Figs 1b, 1c, 2a). In the subsynovial tissue fine granular cytoplasmic staining was present in the perivascular located cells of the stroma (Fig. 1c) and also in hypertrophied endothelial cells of vessels from very inflamed tissues. There was no $\alpha_{2} \mathrm{M}$ otherwise in the vessel walls. The positive perivascular and stromal cells had either an elongated spindle shape (fibroblast like) or were more rounded, corresponding probably to macrophages (histocytes). This morphological impression was confirmed in the following haematoxylin and eosin sections. Diffuse staining was occasionally seen over the synovial surface and on the endothelial surface of vessels, but this was nonspecific as it could not be blocked by the usual inhibition tests (Fig. 2c). Some plasma cells in perivascular areas also showed a nonspecific diffuse staining.

Ig and C3. Fluorescence for Ig and C3 was mainly located in lining cells and in perivascular cells. In the inflamed OA tissues and in the less inflamed RA tissues the LC showed rather diffuse and weak cytoplasmic staining for Ig and C3, whereas in the very

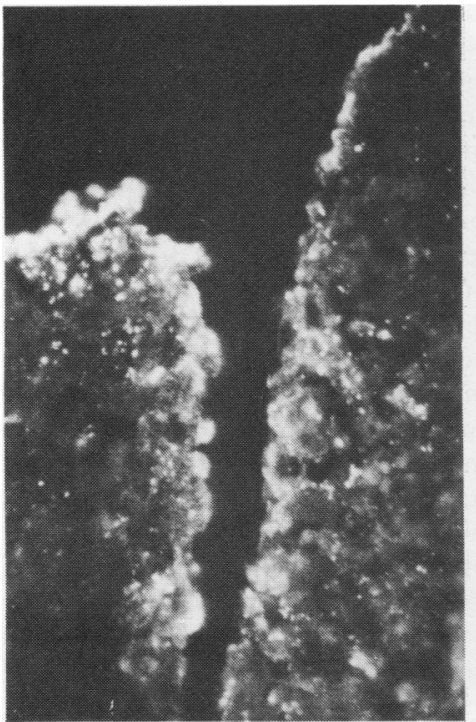

a

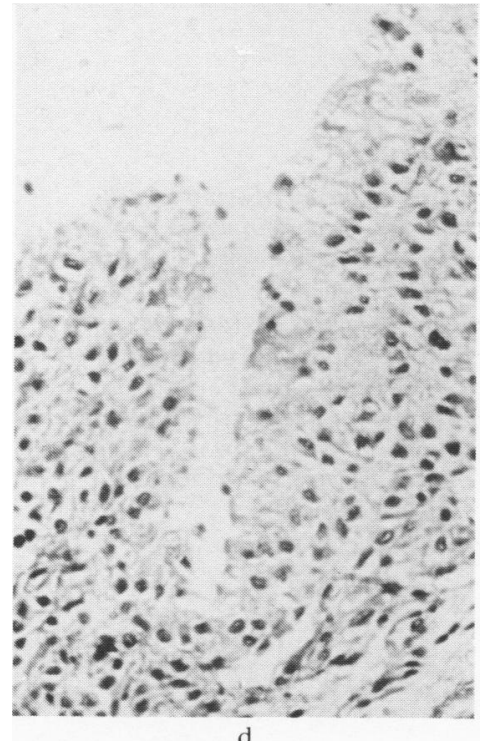

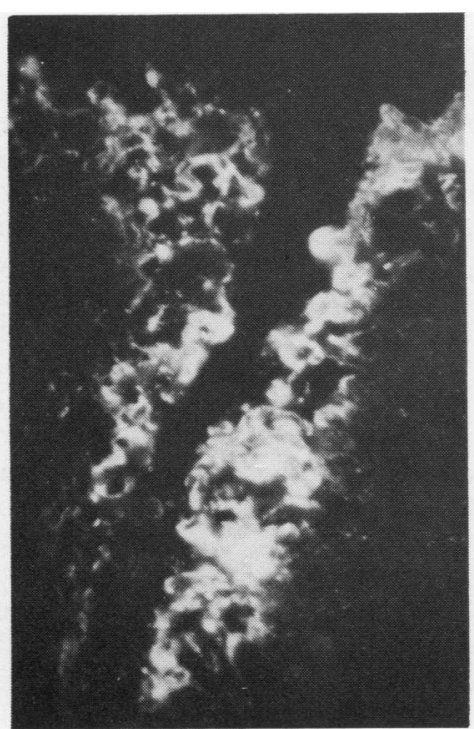

b

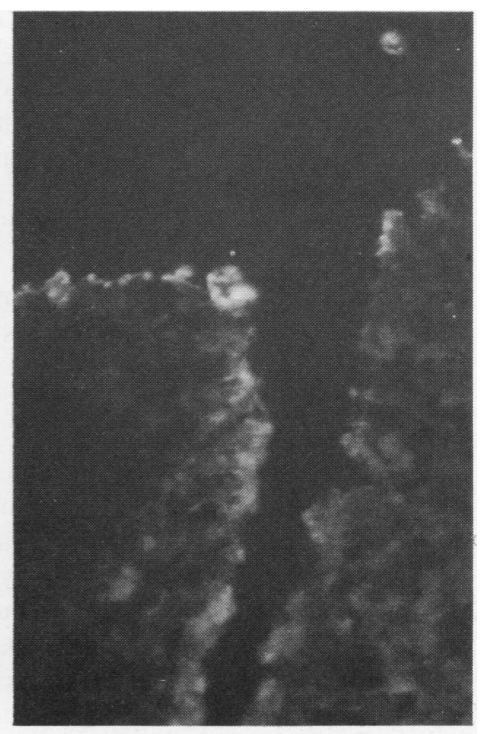

Fig. 2 Rheumatoid synovial membrane (case 4). (a) Immunofluorescent deposits of $\alpha_{2} M(3+)$ in the proliferated lining cells compared with: (b) Immunofluorescent deposits of fibrin in the same area. (c) Negative control. The antiserum against human $\alpha_{2} M$ was absorbed with human $\alpha_{2} M$ before staining. (d) Haematoxylin and eosin staining of the same area showing marked proliferation of lining cells. $(\times 630)$. 
inflamed tissues the pattern was much more intense, with large granular cytoplasmic fluorescence spread over the LC. A few plasma cells showed diffuse cytoplasmic staining with Ig only. There was also evidence of linear Ig and C3 deposits in the vessel walls, but not in the endothelial cells, and some granular deposists were present in the infiltrating mononuclear cells. As with $\alpha_{2} \mathrm{M}$, diffuse nonspecific surface staining was occasionally present. Double staining showed simultaneous localisation of $\mathrm{Ig}$ and $\mathrm{C} 3$ within the LC. Both $\alpha_{2} M$ and Ig were usually seen in the same groups of LC, sometimes even located in the same cell, but more often in separate inclusions.

Fibrin. Fibrin is known to be regularly present in large amounts on the surface and between the LC in various joint diseases. ${ }^{20}{ }^{21}$ Two types of staining with antihuman fibrinogen were present (Fig. 2b): large clumps spread around and over the surface layers of LC and fine granules evenly distributed in the subsynovial tissue, some of which appeared clearly intracellular. These deposits were more prominent in inflamed tissues. No simultaneous staining of fibrin and $\alpha_{2} \mathrm{M}$ was seen.

\section{CELL SMEARS}

In the smears made directly from cells obtained by the trypsin washout technique from RA joints a high proportion of synovial LC (large mono- and polynucleated cells) could readily be distinguished among synovial fluid neutrophil leucocytes and small monocytes (Fig. 3a). When these smears were stained by the immunofluorescence technique, Ig and
C3 inclusions were seen in the LC, smaller mononuclear cells, and neutrophil leucocytes, whereas $\alpha_{2} \mathrm{M}$ was present only in the monocytes and LC (Fig. 3b). After a short period of culture these cells became completely negative when stained for intracellular $\alpha_{2} \mathrm{M}, \mathrm{Ig}$, and C3.

UPTAKE OF $\alpha_{2}$ M TRYPSIN COMPLEXES BY

CULTURED SYNOVIAL CELLS

After being cultured for 24 hours or more, synovial cells assumed either fibroblast-like shapes or a more rounded aspect. The rounded macrophage-like cells were strongly phagocytic ${ }^{17}$ and were predominant during the first days of culture (3-7 days), particularly when cell lines came from a trypsin washout procedure. Thereafter fibroblastic cells frequently became more numerous. Cultures of cells collected by the washout procedure were used within 10 days for the endocytosis experiments, whereas the cells from explants were first cultured for 3 to 6 weeks. The results were identical with both type of cultures. The cells were kept for 4 days in SFM before exposure to $\alpha_{2} \mathrm{M}$-trypsin complexes. About $90 \%$ of the cells exposed simultaneously to plasma and trypsin for 30 minutes contained irregular cytoplasmic inclusions when stained for $\alpha_{2} \mathrm{M}$; the inclusions were found throughout the cytoplasm, particularly in the perinuclear area (Fig. 4a). Similar results were obtained when plasmin was used instead of trypsin. When incubated with plasma alone (SFM+10\% plasma) the cells were usually negative (Fig. 4b). At $4^{\circ} \mathrm{C}$ or in the presence of iodoacetamide no inclusions
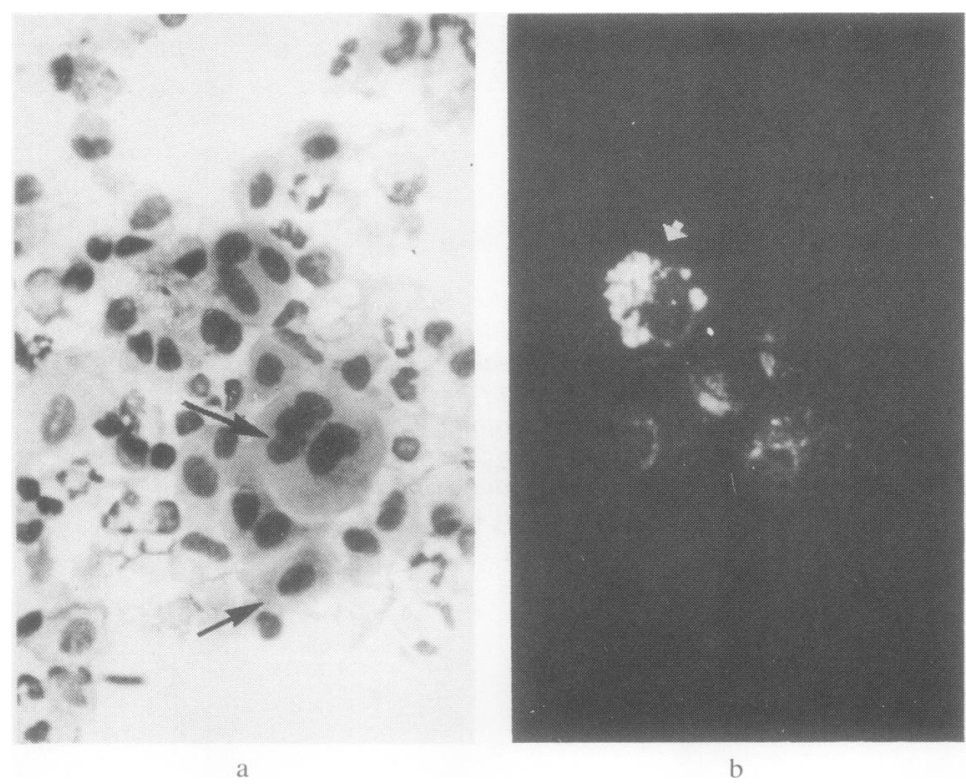

Fig. 3 Smears of synovial cells obtained by trypsin washout of the joint. (a) Haematoxylin and eosin: the large mono- or polynucleated synovial lining cells (arrows) can be easily distinguished among the synovial fluid cells. $(\times 750)$.

(b) Immunofluorescence staining for $\alpha_{2} M$ : deposition of $\alpha_{2} M$ in a large mononucleated synovial lining cell (arrows). (×750). 


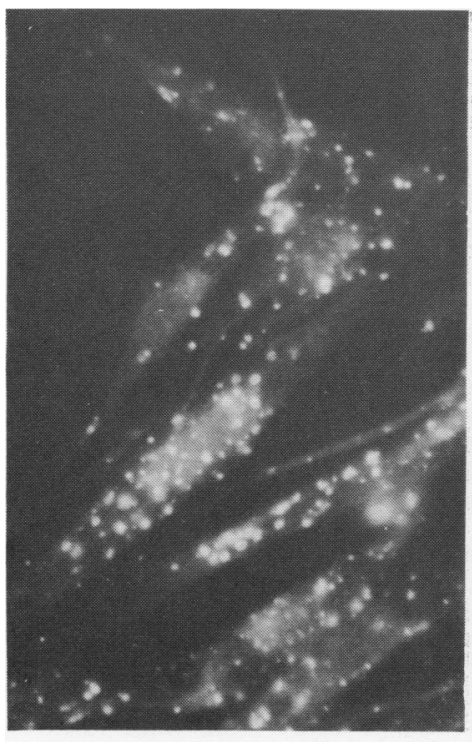

a

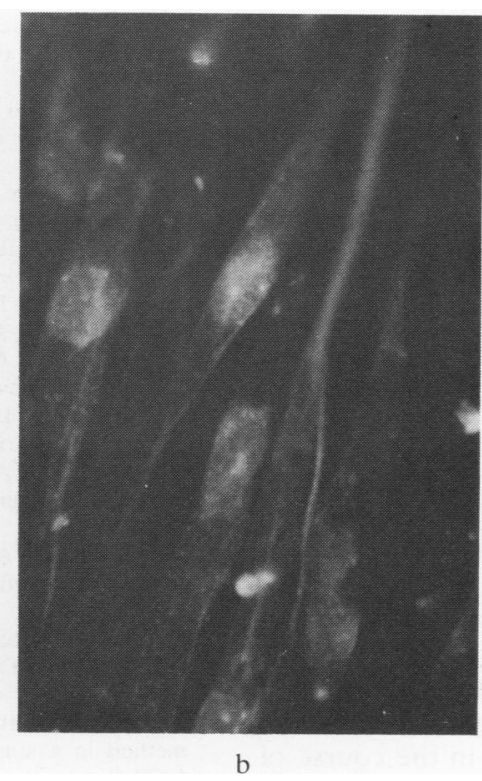

Fig. 4 Synovial cells after 3 weeks of culture. (a) Exposure to SFM and human plasma $10 \%+10 \mu \mathrm{g} / \mathrm{ml}$ trypsin. Immunofluorescence staining for $\alpha_{2} M$ reveals intracellular inclusions corresponding to uptake of spontaneously formed $\alpha_{2} M$-trypsin complexes. $(\times 750)$. (b) Exposure to $S F M$ and human plasma $10 \%$. Immunofluorescence staining for $\alpha_{2} M$ is absent. $(\times 750)$ could be seen. The uptake was time-dependent: after 15 minutes' incubation only $50-60 \%$ of the cells were positive, whereas after 30 minutes nearly all the cells had $\alpha_{2} \mathrm{M}$ inclusions. $\alpha_{2} \mathrm{M}$ was not detected in cells cultured in SFM. When cells showing an uptake of $\alpha_{2} \mathrm{M}$ complexes were put in SFM, their inclusions disappeared progressively and after 12 hours of culture could no longer be detected. No qualitative or quantitative difference in staining was noted between RA or non-RA cells.

\section{Discussion}

The work described in this report demonstrates that synovial cells from the lining layer and perivascular areas in tissues from inflamed joints contain granular deposits of $\alpha_{2} \mathrm{M}$ in close association with $\mathrm{Ig}, \mathrm{C} 3$, and fibrin. The deposits of Ig, C3, and fibrin have been described before, ${ }^{122}$ and their significance will not be discussed here. The $\alpha_{2} \mathrm{M}$ inclusions could correspond theoretically to $\alpha_{2} \mathrm{M}$ produced by the cells, to $\alpha_{2} \mathrm{M}$ taken up in association with immune complexes, complement, or fibrin, or finally to $\alpha_{2} \mathrm{M}$ ingested by the cells in its native form or complexed to proteases. We favour the last hypothesis for several reasons. Macrophages and fibroblasts are known to produce $\alpha_{2} M,{ }^{23}{ }^{24}$ and the latter also take up free $\alpha_{2} \mathrm{M}$ from the medium in-vitro. ${ }^{19}$ With the immunofluorescence technique we found, however, no trace of intracellular $\alpha_{2} \mathrm{M}$ in the synovial cell cultures, except when these cells were exposed to $\alpha_{2} \mathrm{M}$-protease complexes. Such complexes are readily taken up by mac- rophages, as demonstrated by several authors, and can be easily detected by the immunofluorescence method. ${ }^{9}$ As free $\alpha_{2} \mathrm{M}$ has probably a higher concentration in inflamed tissues due to the increased vascular permeability, uptake of free $\alpha_{2} \mathrm{M}$ by fibroblast-like cells in the deeper layer of the synovium cannot be excluded. Macrophages, however, do not take up free $\alpha_{2} \mathrm{M}$ in amounts sufficient to be detected by the fluorescence method. ${ }^{9}$ Therefore it is likely that the granular deposits in the phagocytic lining cells and the macrophage like cells in the perivascular area correspond to $\alpha_{2} \mathrm{M}$-protease complexes. It has been reported that immune complexes bind $\alpha_{2} \mathrm{M}$ nonspecifically. ${ }^{25}$ Flory and Vischer ${ }^{9}$ found, however, no trace of intracellular $\alpha_{2} M$ in macrophages when immune complexes were phagocytosed in the presence of free $\alpha_{2} M$. Similarly, double staining for both $\alpha_{2} \mathrm{M}$ and Ig demonstrated inclusions with $\alpha_{2} \mathrm{M}$ only. That certain inclusions contain both $\alpha_{2} \mathrm{M}$ and Ig could be expected, as macrophages exposed simultaneously to $\alpha_{2} \mathrm{M}$-trypsin complexes and immune complexes contained mixed inclusions. ${ }^{9}$ Whether fibrin can fix $\alpha_{2} M$ is not known. We found no evidence of a close association of fibrin with the $\alpha_{2} \mathrm{M}$ inclusions. Thus the demonstration of $\alpha_{2} \mathrm{M}$ inside certain cells of the inflamed synovial membrane represents, at least in part, the uptake of $\alpha_{2} \mathrm{M}$-protease complexes.

Which proteases are bound to $\alpha_{2} \mathrm{M}$ in the inflamed tissues cannot be determined. Inflammatory cells such as neutrophil leucocytes and macrophages release proteases during phagocytosis, and the latter 
secrete them after activation. Structural cells such as certain lining cells, fibroblasts, and chondrocytes secrete collagenase. As $\alpha_{2} \mathrm{M}$ inactivates most proteases, we would need antibodies to all these enzymes to be able to determine the type of proteases.

Whether the $\alpha_{2} \mathrm{M}$-protease complexes are formed in the tissues or come from the synovial fluid is not clear. As degradation of $\alpha_{2} \mathrm{M}$-trypsin complexes was demonstrated in the synovial cell cultures within 12 hours, it is very likely that the synovial deposits correspond to recently formed $\alpha_{2} \mathrm{M}$-protease complexes.

The uptake of $\alpha_{2} \mathrm{M}$-protease complexes by synovial cells gives indirect evidence for release of active proteases at sites of inflammation. These complexes might have other effects as well. Recently it has been demonstrated that endocytosis of such complexes by macrophages activates these cells to secrete other neutral proteases ${ }^{26}$ which might be a factor in selfperpetuation of inflammation. An immunoregulatory role of $\alpha_{2} \mathrm{M}$-protease complexes has recently been proposed which might have implications for the deranged immunological processes in the course of rheumatoid arthritis. ${ }^{27}$

This work was supported by a scholarship from the Swiss National Fund and by grants from the Australian Arthritis and Rheumatism Foundation, the Rheumatism and Arthritis Association of Victoria, and Lilly Industries Pty. Ltd., and a financial contribution from Holderbank Stiftung, Switzerland. The authors are grateful to Dr J. R. E. Fraser for advice with the cell cultures and also to Drs G. Burns and $K$. Rogers for their advice and technical help. Dr T. L. Vischer, Geneva, helped in designing the experiments and with the manuscript.

\section{References}

1 Bagglioni M, Bretz B, Dewald B, et al. The polymorphonuclear leukocyte. Agents Action 1978; 8: 3-8.

${ }^{2}$ Allison A C, Ferluga J, Poyz H, et al. The role of macrophage activation in chronic inflammation. Agents Action 1978; 8: 27-33.

${ }^{3}$ Deshmukh-Phadke K, Nanda S, Lee K. Macrophage factor that induces neutral protease secretion by normal rabbit chondrocytes. Eur J Biochem 1980; 104: 175-80.

4 Dayer J M, Krane S M, Russell R G, Robinson D R. Production of collagenase and prostaglandin by isolated adherent rheumatoid synovial cells. Proc Natl Acad Sci USA 1976; 73: 945-9.

${ }^{5}$ Heimburger N. Proteinase inhibitors of human plasma-their properties and control functions. In: Reich E, Rifkin D B, Shaw E, eds. Proteases and Biological Control. Cold Spring Harbor Laboratory, $1975 ; 367-86$.
- Ohlsson K, Laurell C B. The disappearance of enzyme-inhibitor complexes from the circulation of man. Clin Sci Mol Med 1976; 51: 87-92.

7 Granelli-Piperno A, Reich E. A study of proteases and proteaseinhibitor complexes in biological fluids. J Exp Med 1978; 148: 223-34.

s Abe S, Nagai Y. Evidence for the presence of a complex of collagenase with $\alpha_{2}$ macroglobulin in human rheumatoid synovial fluid: A possible regulatory mechanism of collagenase activity in vivo. J Biochem 1973; 73: 897-900.

- Flory E, Vischer T L. $\alpha_{2}$ Macroglobulin as an inclusion in synovial fluid monocytes. Rheumatol Int 1981; 1: 61.

${ }^{10}$ Luscombe M. Acid phosphatase and catheptic activity in rheumatoid synovial tissue. Nature 1963; 197: 1010.

11 Muirden $\mathrm{K}$ D. Lysosomal enzymes in synovial membrane in rheumatoid arthritis. Ann Rheum Dis 1972; 31: 265-71.

12 Fish A, Michael A F, Gewurz H, Good R A. Immunopathologic changes in rheumatoid synovium. Arthritis Rheum 1966; 9: 267-80.

13 Sainte-Marie G. A paraffin embedding technique for studies employing immunofluorescence. $J$ Histochem Cytochem 1962; 10: 250-6.

14 Holborow E J, Johnson G D. Immunofluorescence. In: Weir D M ed. Handbook of Experimental Immunology. Oxford: Blackwell, 1967: 571-96.

${ }^{15}$ Fraser J R E, Catt K S. Human synovial cell culture. Use of a new method in a study of rheumatoid arthritis. Lancet 1961; ii: 1437-9.

${ }^{16}$ Fraser J R E, McCall J F. Culture of synovial cells in vitro. Ann Rheum Dis 1965; 24: 351-9.

${ }^{17}$ Clarris B J, Fraser J R E, Moran C J, Muirden K D. Rheumatoid synovial cells from intact joints (morphology, growth and polykaryocytosis). Ann Rheum Dis 1977; 36: 293-301.

${ }^{18}$ Clarris B J, Fraser J R E. On the pericellular zone of some mammalian cells in vitro. Exp Cell Res 1968; 49: 181-93.

19 Pastan I, Willingham M, Anderson W, Gallo M. Localisation of serum derived $\alpha_{2}$ macroglobulin in cultured cells and decrease after Moloney sarcoma virus transformation. Cell 1977; 12: 609-17.

${ }^{20}$ Zvaifler N J. The immunopathology of joint inflammation in rheumatoid arthritis. Adv Immunol 1973; 16: 265-336.

${ }^{21}$ Soren A. In: Soren A, ed. Histodiagnosis and Clinical Correlation of Rheumatoid and Other Synovitis. Stuttgart: Thieme, 1978: 26.

${ }^{22}$ Fryand $\mathrm{O}$, Mellbye $\mathrm{O} \mathrm{J}$, Natvig J B. Immunofluorescence studies for immunoglobulins and complement $\mathrm{C} 3$ in synovial membrane in psoriatic arthritis. Clin Exp Immunol 1977; 29: 422-7.

${ }^{23}$ Hovi T, Mosher D F, Vaheri A. Cultured human monocytes synthesise and secrete $\alpha_{2}$ M. J Exp Med 1977; 145: 1580-9.

${ }^{24}$ Mosher D F, Wing D A. Synthesis and secretion of $\alpha_{2} M$ by cultured human fibroblast. J Exp Med 1976; 143: 462-7.

${ }^{25}$ Lavergne M, Raynaud M. Preparation et propriétés de l' $\alpha_{2} M$ du cheval. Ann Inst Pasteur (Paris) 1970; 119: 27-49.

${ }^{26}$ Vischer T L, Berger D. Activation of macrophages to produce neutral proteinases by endocytosis of $\alpha_{2} \mathrm{M}$-trypsin complexes. $J$ Reticuloendothel Soc 1978; 28: 427-35.

27 Teodorescu M. Characterization and role in autoimmune diseases of the polyclonal $\beta$-cell activator produced by $T$-cells - the helper factor. Immunol Rev in press. 